\title{
Creativity in the 16th-century representation of King Sebastião's in the Battle of Ksar-el-Kebir
}

\author{
Ana Paula AVELAR \\ Universidade Aberta, Lisboa, Portugal \\ CHAM, FCSH Universidade NOVA de Lisboa e CEC, CH, Universidade de Lisboa \\ Email: ana.avelar@uab.pt \\ ORCID: 0000-0003-0482-3832
}

\begin{abstract}
The concept of Hero lies at the core of this analysis of its representation and of how creativity, intuited as a process that results from the interaction between the authors of the several chronicles and their readers in two texts, king Sebastião's Journey in Africa and Sherif Mulei Mahamet's Chronicle. The analytic topos is the moment of the battle of Ksar-el-Kebir and the echoes put forward by the authors who gathered information and described the actions of the various actors in the conflict, focusing on the representation of the hero and the authorial creativity therein exposed.

King Sebastião's Journey in Africa and Sherif Mulei Mahamet's Chronicle help us to decode the way this monarch's profile was shaped. It is in the confrontation of narrative modelling of the hero, as an example and persona chiara/scura, that actors, authors and textual purposes are uncovered, where the tone of voice and peroration cross the writing of a battle and those who were its "publicos".
\end{abstract}

Keywords: Hero; Creativity; Ksar-el-Kebir; Chronicle; King Sebastião

While approaching the hero's profile in some Sebastian chronicles, we try to answer some of the questions that arise when we ponder on the way history was written throughout the 16th-century, and touching a specific topos the one meant by the military narrative. On the other hand, I am in line with the concept of topos as an active association node for ideas, representing categories and relations that can function as heuristic models; space where situations or events can be placed, categorised and organised in their own way In the case of the Sebastian chronicles, I devote myself to the hero's topos, uncovering him, taking into account the inherent creativity as a process that results from the interaction established between the authors and their readers. Yet in this process, another concept, that of originality, must be taken into account (Pope, 2005, p. 60). In the case of historical discourse, this concept often is allied to the use of sources, hitherto unknown.

We agree that

Creativity requires novelty; the obvious contrast to creativity is mere repetition and replication. But not every kind of novelty will do; diverging from established practice is not considered creative if it does not lead to a positive result. (Klausen, 2010:349)

These frontiers must be conceived within Camilla Nelson's synthesis that somehow echoes Michel Foucault:

Creativity is an invention brought about by a particular arrangement of knowledge that saw the birth of the humanist subject. (Nelson, 2010:69)

Its nature is somehow fluid since as Foucault himself declares

One thing in any case is certain: man is neither the oldest nor the most constant problem that has been posed for human knowledge. Taking a relatively short chronological sample within a restricted geographical area-European culture since the sixteenth century one can be certain that man is a recent invention within it. (Foucault, 2005, p. 422)

The writing of human actions is conceived within correlation between memory and historiography, hoping that both have to be plausible (Catroga, 2017, p. 69). Therefore, while analysing the Sebastian chronicles, we must inscribe them in the model that was chosen by their own authors since historical narrative culturally echoes the society whence it was born and also is part of the historical process.

We do not follow modernist empiricism that, since the 19th-century, has been considering historiographical narrative as an impersonal discourse, which confines itself to the recounting of facts, e.g., the assumption of the writing of History as something free from masks or artifices. As Alain Munslow sharply shows:

This vision of the history as a practice fails to acknowledge the difficulties in reading the preexisting narrative constituted as evidence, or the problems of writing up the past. (Munslow, 2003, p. 10)

Thus, while searching for the unveiling of the unsaid in the reading of the images that run through the meaning of the text, we seek the ultimate purpose of the writing of History through the deconstruction of data and their perception within a historical frame. This analysis of the historical condition, and of what is revealed in it of creativity, echoes Paul Ricoeur when he claims that:

I will call our "historical condition" this realm of 
existence placed under the sign of a past as being no longer and having been. And the assertive vehemence of the historian's representation as standing for the past is authorized by nothing other than the positivity of the "having been" intended across the negativity of the "being no longer." Here, we have to admit, the epistemology of historiographical operation reaches its internal limit in running up against the borders of an ontology of historical being. (Ricoeur, 2004, p 422)

We must ponder then on how the Ars Historica was conceived in Portugal in the 16th-century, and how tradition and novelty were therein reflected in a time when in Claude-Gilbert Dubois' words: "The return to the ancient becomes the novelty of the times, or more exactly leads to a renewal." (Dubois, 2001, p. 11) ${ }^{1}$

Here lies History writing process. It embodies itself as an instrument of legitimation of power, namely of a kingdom, thus emulating a time, and eventually immortalising it. It is true that, as we have repeatedly shown, the chronicle describes the past events throughout the life of a monarch and his reign.

During the 16th-century, Portugal witnesses the emergence of two trends in a historical narrative: the king's and the Expansion' chronicle. These distinct models of writing follow the same concept of History and support their authors' need to get access to those who lived in the spaces that are described and that had witnessed specific events. Along with these two models of writing History, we find a whole series of texts that relate to personal experiences. The historical time they describe is shorter since the narrative focuses on an event confined in time, and on an experience/testimony that validates the historical narrative of events. This is all the more evident when we dwell on the descriptions of military deeds, such as king Sebastião's expedition to Morocco.

As mentioned above, this essay devotes itself to the analysis of those two texts that describe the young king's last and fateful journey. Both narratives describe the events, the actions and the monarch's profile within a light/ dark atmosphere. Serving the king, struggling for the motherland and eventually dying for it, is the contrastive recurrence where lies the creativity in these historical narratives, thus subscribing the previously defined hermeneutic boundaries.

The summary of all the things that happened in Berberia, since the time [when] Xarife Mulei Mahamet started to reign in 1573, until the end of

1 Le retour à l'antique devient la nouveauté des temps, ou plus exactement conduit le renouveau.

2 Alcácer Quibir.

3 O sumário de todas as coisas sucedidas em Berberia, desde o tempo (em) que começou a reinar o Xarife Mulei Mahamet no ano de 1573, até ao fim do ano da sua morte, 1578, no dia da Batalha de Alcácer-Quibir, em que se the year of his death, 1578, in the battle of Ksar-elKebir $^{2}$, where Sebastião king of Portugal was lost ${ }^{3}$ lies upon the point of view of one of António prior do Crato's servant, whose identity remains unknown.

The expedition is the central theme of the historical narrative, while the author testifies to what he may have witnessed in the battlefield, where he was captured and eventually led to Fez where he remained imprisoned. Here he listened to other testimonies that he mentions throughout his narrative. His master's Antonio profile is signalled, in particular when he describes the disagreements that he is supposedly having had with the king. This actually is a discourse about a dysphoric time. From this event there resulted, as he writes in the opening of her first chapter, to the "sad Kingdom of Portugal, so many calamities, so many misfortunes and so many accidents, matter, by the variety and grandeur of it worthy of memory." (Loureiro, 1987, p. 101) ${ }^{4}$

On the other hand, the anonymous text attributed to Fernando de Góis Loureiro, and untitled Journey of King Sebastião to those parts of Africa where he was lost during the battle he fought with the moors in the year 1578 of our Era ${ }^{5}$ follows the king chronicle's model, although it is mainly focused on the expedition. The anonymous author seeks to convey the example of History since this is a discipline for the knowledge and learning of kings and princes.

I recall, very briefly, that as soon as he was born king Sebastião was offered the Sentences of various authors that reveal the kings the way they must behave both in peace and in war, and how they should rule (Évora, 1993). The prince is one who, on the one hand, must master the exercise of weapons and, on the other, must know the past, since this is a source of teaching that relies on the examples that may help a good government.

King Sebastião's education takes place in an imperial time when the pen was supposed to serve the king, and when Portuguese men of letters sought to write an epic about the nation's deeds. Besides the frontiers between Ars Historica and Ars Poetica were anchored in the Aristotelian definition of their own specific functions: one should describe what had happened, and the other what could have happened (Aristotle, 1986, p. 115). In the 16thcentury, the epic tone echoes in History writing, namely in Expansion History, and, as we have mentioned above, History plays a particular

perdeu D. Sebastião, Rei de Portugal.

4 triste Reino de Portugal, tantas calamidades, tantos infortúnios e tão vários acidentes, matéria, pela variedade e grandeza dela digna de memória

5 Jornada de ElRei Dom Sebastião as partes de Africa aonde se perdeo na Batalha que deu aos Mouros em o ano \& Era de 1578 . 
function in the future king's education, bearing in mind his future status. We do not agree with those who consider these fields - epic and History - to be rivals since both play a part in the prince's education; even if they use different models of writing, yet they serve an ethical purpose (Avelar, 2004, p. 40)

When he was fourteen king Sebastião wrote a brief memory where he put considered that the monarch should be at God's service, propagate the faith, defend the rule of law, justice and morality, punish those who break it and permeate those who fulfil it, thus being an example for those he rules (Buescu, 1996, p. 249)

However, the various voices that describe the king's profile expose the author's creativity in the way they try to approach the reader. But it is important to remind that in the narrative of the Journey, Sebastião emerges as the Intended Monarch. This text follows obvious rhetorical prosody, where the metaphorical sentence invades the discourse. It should be noted that during the minority and the early years of the king's rule a Muslim dominion prevailed: the Turkish' and the Safavid's empires, the Maghreb Moors and the Islamized peoples in the Indian Ocean, which threatened the movement of European kingdoms, especially the Iberian powers.

The victory of King John of Austria at Lepanto in 1571 stalled this Muslim irradiation, although it was necessary for the European powers to strengthen their positions, thus rebalancing their forces in the Mediterranean. Portugal intended to extend and consolidate a Portuguese empire in Berberia.

We do not draw here all the conjuncture-long that contextualise the expedition of Ksar-el-Kebir. We only point out conjuncture traits that illuminate the historical discourses analysed in this essay. Both the Summary [...] and the Journey [...] focus on the near past. The first text was written by a Portuguese captive in Fez after the battle, while the second, written between 1588 and 1595, would be, as we mentioned above, attributed to Fernando Góis Loureiro who consulted various sources and collected testimonies.

Although, in a different way, the Portuguese king's action in the Berber scenes of war is the narration space par excellence. The sojourn of the young monarch in the summer of 1574 in Ceuta and Tangier pointed to the choice of the Maghreb area as a territory where Portuguese actions aimed at stopping Turkish expansionism in the Western Mediterranean. The dynastic succession in Morocco is the main reason for Portuguese

6 E assim como se lhe pôs este nome novo, assim com novos e desses costumados extremos procedeu em grandes danos daquele miserável povo [Portugal] que com intervention. In 1557, after the murder of Mawlay Muhammad Shaykh, his son Mawlay 'Abd Allâh alGalib came to the throne, leaving his brothers, Mawlay'Abd al-Malik (Mulei Maluco, according to the designation of Portuguese chronicles) and Mawlay Ahmad (Mulei Amet), offering their services to the Turks.

After the death of the king of Mawlay 'Abd Allâh alGalib (1574) his son Mawlay MuhammadalMutawakkil (Mulei Mahamet) succeeded him, yet he did not follow the designs instituted by the founder of the dynasty. Abd al-Malik, who had shown himself at the service of the Turks, obtained his support for his claim to the Moroccan throne, fighting his nephew, defeating him and thus being proclaimed sultan.

Although Mawlay Muhammad al-Mutawakkil sought aid from Spain, he was not successful. Instead, king Sebastião answered affirmatively to his appeal. An expedition would thus be put into place, despite the difficulties due to the lack of men and financial resources. The author of the Summary is, at this level, rather eloquent, emphasising the dissolution and famine that were felt during the provision of the fleet. The Journey also mentions the huge expenses required by the preparation of the expedition, although one witness constant support of the young monarch. Without developing an exhaustive analysis of the different moments of the combat, we must remind that on August 4, 1578 , the Portuguese army led by the king, who had joined the Moorish forces of Mawlay Muhammad and some Flemish, German, and Italian mercenaries, confronted 'Abd al-Malik who was supported by his brother Mawlay Ahmad, who eventually won the battle. Mawlay Ahmad would die drowned, and 'Abd al-Malik would die of disease or presumably poisoned. King Sebastião would disappear in combat.

These events are broadly described in both texts. In his Summary, Antonio's servant unveils his own experience, while the Journey's author, maybe Fernando Góis Loureiro, describes the king's action, the so-called desired young monarch, Sebastião.

In this latest narrative, the pathos flows in the first pages along with the tragic hubris, as conceived by Aristotle, an excessive pride that eventually leads to the hero's fall. Thus is creativity put forward,

\footnotetext{
And thus as a name was given, thus with new and with great damage that miserable people [Portuguese] with tears reached it, and with sorrowful performance saw him definitely lost. And thus often men search and wish to achieve things that, when achieved, swiftly lead to destruction what they had longed for before. (Loureiro, 1978, p. 13) ${ }^{6}$
}

lágrimas o alcançou, e com lacrimoso e triste espectáculo o veio a perder de todo. E assim muitas vezes procuram os homens e desejam conseguir cousas que alcançadas são 
It is within a short temporal arc that both narratives focus king Sebastião's expedition. It is in the heat of a dysphoric present that the facts are recorded and that the Art of History is exercised. The memory of the deeds is narrated, describing the action of the men and their prince, Sebastião. This was the monarch who had received from the hands of the Spanish captain Francisco de Aldana, the envoy of the Duke of Alba, a gavel and a coat of arms used by his grandfather Carlos $V$ in the conquest of Tunis. Sebastião inscribes himself thus in the mirror of princes, under the protection of his grandfather Carlos V, that king on whom Baltasar Gracián and Morales wrote, in The Hero (1637) that

\section{The augustly House of Austria came to be a marvel of lineages, founding its greatness in that it is a cypher of the wonders of God. And he has anointed his imperial blood with that of Christ, Our Lord, the Blessed One [...]. Being a hero of the world, little or nothing is; to be of Heaven is much, to whose great Monarch praise is given, if honour be given, glory be rendered. (Gracián y Morales, 2003, p. 86) $^{7}$}

The hero who is in a Modern regulated state, the wise warrior, servant of a nation.

King Sebastião aspires to be the auroral hero, the one who lives for action and honour and who, as stated Daniel Madelénat, appears to us: "Devoid of hiatus between self and persona, between free consciousness and insane body" (Medelénat, 1986, p. 55$)^{8}$.

The Portuguese captive in Fez traces a heroic profile of Mulei Mafamed. According to him, the latest had many qualities, not those of a barbarian king, but a very excellent prince. He would be a valiant soldier, pleasant in his dealings, magnanimous and liberal, with a soft and affable condition, so cheerful in his speech, that he was eloquent both in his own language and in Turkish; besides, he also was acquainted with French, Spanish, and Italian. While with his army, he was reading Orlando the Furious and other writings in the languages he knew. In the words of our captive, he was an admirer of Carlos V and asked for all the books that could be found on the history of that emperor (Loureiro, 1987, p. 69). The text's description of Sebastião fulfils the aulic profile of the monarch, who is consubstantiated as the universal mirror of all the maxims, what he

abreviada destruição do que pretendem.

7 Veio a ser maravilha de linhagens a augustíssima Casa da Áustria, fundando a sua grandeza na que é cifra das maravilhas de deus. E rubricou o seu sangue imperial com o de Cristo, Nosso Senhor, sacramentado. [...] Ser herói do mundo, pouco ou nada é; sê-lo do Céu é muito, a cujo grande Monarca se preste o louvor, se preste a honra, se preste a glória.

8 Dépourvu d'hiatus entre un moi et une persona, entre conscience libre et corps aliéné.

9 émulo comum de todos os heróis a quem é centro de todas as proezas, e equivoque-se o aplauso em brasões

\section{seeks to be}

[...] a common hallmark of all heroes to whom he is the centre of all prowess, and the applause in coats of arms with eminent plurality is mistaken: the fortunate, for happiness; the brave, for the value, the discreet, for the ingenuity; the most Catholic, for his heaven; the fearless, by his gracefulness; and the universal, for all. (Gracián y Morales, 2003, p. 77). ${ }^{9}$

Yet the dysphoria of the present echoes in the laudatory grammar of this chronicle. The author, known as Fernando de Góis Loureiro, imposes an elegiac tone, redeeming the king of all the faults imputed to the masters. There lies his creativity because his prince is what, through education

not contented with the glory of those above him wished to change his peace, and disturb the rest and quietness of his vassals, and finally seek his ruin in the unnecessary dangerous and difficult conquest of other kingdoms. (Loureiro, 1978, p. 17) ${ }^{10}$

He is the one who, while facing danger, in the heat of the battle

[...] saw dying before him so many and so good lords [that he] wished to die like them and so he got into the greatest dangers, yet his invincible animus allow him to stay alive. (Loureiro, 1978, p. 116) ${ }^{11}$

His performance in the battle actually is one of a fierce Christian knight.

In turn, Antonio's servant, despite criticising the king, namely by challenging his military decisions, still recognises his worth in the battlefield. According to him, the Portuguese are an example to be followed (Loureiro, 1987, p. 204). Sebastião had listened to ambitious flatterers who have assured him that honour was not achieved through weakness, nor by listening to deferential advice (Loureiro, 1978, p. 164)

It is the testimony that shows experience: passions are exposed in a tone that touches rhetoric, although it does not follow the elegiac lament of the king's Journey in Africa, nor the peroration that closes the life of the monarch (Loureiro, 1978, p. 141). It is within hubris that the symbolic representation of the king persists, as evidenced by authorial creativity.

A contrastive atmosphere of light/dark pervades in the writing of Sebastião's expedition in Africa. Here lies the key to the reading of the creative process as com eminente pluralidade: o afortunado, pela felicidade; o animoso, pelo valor, o discreto, pelo engenho; o catolicíssimo, pelo seu céu; o destemido, pela sua airosidade; e o universal, por tudo.

10 não contente com a glória de seus maiores quis alterar seu sossego, e perturbar o repouso e quietação de seus vassalos e finalmente procurar sua ruína na desnecessária perigosa e difícil conquista de reinos alheios.

11 viu morrer diante de si tantos e tão bons fidalgos desejoso de acabar com eles se meteu nos maiores perigos mas de todos seu animo invencível o tirou com vida. 
exercised by the two authors we have been analysing. The possible mimicking of these strategies of representation of the monarch in other narratives, and the correlations with their readers are analytical paths that must be further explored, given that

we should grasp creativity functionally in terms of what it does; or frame it socially in terms of who, where and how; or simply develop the historical view of what being creative has meant. (Pope, 2005, p. 52)

And this must be achieved while never forgetting the historical condition of our object of study, as a sharp critic that does not ignore the limits of historical knowledge.

\section{Acknowledgement:}

This study is part of the project «De Re Militari“De Re Militari: Da escrita da guerra à imagem do campo de batalha no espaço português (15211621)"-PTDC/ART-HIS/32459/2017"

\section{Bibliographical References:}

Aristóteles. (1986). Poética. Lisboa: Imprensa Nacionalcasa da Moeda.

Avelar, Ana Paula. (2004). Do perfil do Herói em algumas crónicas sebásticas, in Academia Portuguesa de História, Colóquio - O Sebastianismo - Política doutrina e mito (sécs. XVI-XIX). Lisboa. Edições Colibri.

Buescu, Ana Isabel. (1996). Imagens do Príncipe - Discurso normativo e representação (1525-1549). Lisboa: Edições Cosmos.

Catroga, Fernando. (2017). "O Historiador na cidade :História e Política", in Matos, Sérgio Campos e João, Maria Isabel (org.) Historiografia e Res
Publical. (pp. 27-86). Lisboa: CH-CEMRI.

Dubois, Claude-Gilbert. (2001). Le Bel aujourd'hui de la Renaissance.-Que reste-t-il du XVle siècle? Paris: Seuil.

Évora, André Rodrigues de. (1993). Sentenças para a Ensinança e Doutrina do Príncipe D. Sebastião. Facsimile do manuscrito inédito da Casa do Cadaval, Lisboa: Banco Pinto \& Sotto Mayor.

Foucault, Michel. (2005). The Order of Things, An archaeology of the human sciences. London: Routledge.

Gracián y Morales, Baltasar. (2003). O Herói. Lisboa: Frenesi.

Kantarowics, E. (1984) Mourir pour la patrie. Paris: PUF.

Klausen, Søren Harnow. (2010). The Notion of Creativity Revisited: A Philosophical Perspective on Creativity Research. Creativity Research Journal, 22 (4), pp.347-360.

Loureiro, Francisco Sales (ed). (1987). Crónica do Xarife Mulei Mahamet e d'el-ReiD. Sebastião. Odivelas: Europress.

(ed.). (1978). Jornada del-rei dom Sebastião à África - Crónica de dom Henrique. Lisboa: Imprensa Nacional-Casa da Moeda.

Medelénat, Daniel. (1986). L'épopée. Paris: PUF.

Munslow, Alain. (2003). Deconstructing History. London: Routledge

Nelson, Camilla. (2010). The Invention of Creativity-The Emergence of a Discourse. Cultural Studies Review, 16 (2), pp. 49-74.

Pope, Rob. (2005). Creativity: Theory, History, Practice. London: Routledge.

Ricoeur, Paul. (2004). Memory, history, forgetting. Translated by Kathleen Blamey and David Pellauer. Chicago: University of Chicago Press. 